\title{
Comparative Review Between Covid-19 and Stunting: Communication Framework Toward Risk-Mitigating Behavior
}

\author{
Silva Liem ${ }^{1}$, Rustono Farady Marta ${ }^{2}$, Hana Panggabean ${ }^{3}$, Clara R.P. Ajisuksmo \\ 1,23,4Faculty of Psychology, Universitas Katolik Indonesia Atma Jaya \\ ${ }^{2}$ Magister of Communication Science, Universitas Bunda Mulia
}

Submitted 22 September 2020 Accepted 23 October 2020 Published 22 December 2020

\begin{abstract}
In addition to Covid-19, stunting is another threat facing Indonesia. Although not as deadly as Covid-19, stunting requires immediate responses; otherwise it will burden our development agenda. Substantial evidences from application of Theory of Planned Behavior (TPB) accumulate significant relationship of health intentions to individuals' behavior. Further extension of TPB that includes other variables confirms the role of knowledge and risk perception in predicting health intentions and behavior. Similarly, involve risk factors within public health area, risk communication of Covid-19 seems outperforms that of stunting. Using TPB's perspective, this review of literature aims to analyze health promotion impacts of these health threats. Result indicates differences in risk communication strategy for Covid - indicated by emerging amateur health promoters - as to stunting. There is a need for intensive collaboration of Psychology and Communication studies in exploring communication strategies to help building health intentions toward performing risk-mitigating behaviors beyond Covid-19 and stunting alone.
\end{abstract}

Keywords: covid-19; risk communication; stunting theory of planned behavior

\section{Introduction}

As novel ${ }^{1}$ Corona Virus Disease 19 (Covid19) strikes almost all countries, human beings come to realize that their hygienic behavior does have an impact on the health of the community as a whole. The deadly virus has claimed more than 920.000 lives world-wide.

As global epidemiologists are getting familiar with this disease, three behaviors have been suggested to prevent further

\footnotetext{
${ }^{1}$ Address for correspondence: silva.liem@gmail.com
}

spread of the virus: hand-washing with soap (HWWS), wearing mask, and keeping distance from one another (World Health Organization, 2020). Particularly about social distancing, certainly it is not easy for a human being to 'discount' their very nature of social creatures. Although they are fully aware of the consequences when infected with the killer virus, they may not voluntarily avoid meetings with other people, or refrain from mere gettogether activities. While risk-mitigating behavior is clearly identified and widely promoted, incompliances to Covid-19 
protocols have become so common despite uncontrollable hikes. Local government report showed significant number of private as well as public behavior that is counter-productive to risk-mitigating behavior: during September $28^{\text {th }}$ to October $3^{\text {rd }}$ there were as many as 637,102 incompliances reported in ten districts of West Java province (Kurniawan, 2020); while Jakarta posted 5,815 people were fined due to violating Covid-19 protocols on September 19 $19^{\text {th }}$ alone (Prabowo, 2020). Abandoning health protocols during Covid-19 pandemic is found not only among ordinary community members, as there were 243 violations involving political parties and election contestants were reported not adhere to keeping social distance, or not wearing masks (Septiani, 2020).

Concurrently, most of developing and under-developed countries have to deal with stunting, a poor nutritional issue facing children under 5 years old. Representing nutritional problems, stunting is brought by both nutritionspecific and nutrition-sensitive risk factors (Kementerian Kesehatan, 2016), including poor hygiene behavior (Rah et al., 2015; WHO \& UNICEF, 2015). Open defecation (OD) and unsafe disposal of child feces have been closely linked to a higher incidence of stunting (Danaei et al., 2016; García Cruz et al., 2017; George et al., 2016; Spears, 2013) by allowing the transmission of bacteria and fecal pathogen among infants (Danaei, 2016; George et al., 2015). Furthermore, Harris et al. firmly concluded that community latrine coverage significantly determines child growth. In addition to being so clearly identified as risk behavior for stunting, even though people are aware that defecating in the open is disgusting, shameful, and regarded as an improper act (Devine, 2009), it is still practiced by more than 32 million people across the country. Various factors contributed to such practice including lack of knowledge of its impact to health and limited financial capacity to build their own toilets (Gargita, Miswan, \& Rosnawati, 2020; Junias, Mukono, \& Purnomo, 2016; Putra \& Selviana, 2017; Yulyani, Dina Dwi, \& Kurnia, 2019). In addition, respondents found availability and proximity of river streams, bushes nearby their houses as 'enabling' factor for them to continue practicing OD behavior (O'Connell, 2014; Zahtamal, Chandra, Restila, \& Restuastuti, 2020). Other study revealed traditional beliefs and norms such as sharing toilet with others may invite evil spirit, children's feces are not harmful, or accumulating feces into one spot create bad luck have significant and direct influence to school children defecating in the open (Adjibolosoo, Adongo, TawiahYirenya, Ofori, \& Afranie, 2017). Taking such findings into account, a great number of researchers recommended behavior change at community level and utilization of various systematic frameworks (Devine, 2009; Liem, Marta, \& Panggabean, 2019; Perez et al., 2012) to create better quality of environment health, particularly to stop open defecation practices.

Eminently, risk factors of both Covid19 and stunting present serious challenges in public health, where one's behavior or personal hygiene has a direct impact on others in the same community. Public health fails when a few members deviate from healthy practices, rather, it requires 
each community member to adapt only hygienic behavior and do it collectively. In order to better mitigate risk factors, the global community encourages each country to advocate those identified hygiene practices to their local communities. Compatible with the global community's efforts to better control the prevalence of Covid-19, Indonesia has been carefully devising public health strategy while keeping economic sacrifice as low as possible. Almost all local government issue regulations on how to maintain distance from each other, practicing HWWS, wearing a mask (Arditama \& Lestari, 2020; Zahrotunnimah, 2020); some even apply sanctions for incompliances. Immediately, health promotion stakeholders seem to find the biggest stage for they have to convey the risk factors in competition with increasing incidences. The majority of community members demonstrate compliance with those riskmitigating behaviors, probably due to massive promotion by health authorities together with a broad range of stakeholders -including prominent public figures and former Covid-19 patients who suddenly turn themselves into health promotors. On the other hand, with respect to OD behavior that is a major risk factor for stunting, bringing people into ODF communities is yet facing social and economic challenges, such as lack of toilet defecation as a social norm (Kasri, Wahyuningrum, \& SNV, 2019; Odagiri et al., 2017); in addition to low financial capacity, particularly evident in poor households. As a result, only 47 districts in 13 provinces - out of 514 districts nationwide - who have attained ODF status; that is everyone in those districts has adapted in-toilet defecation behavior.
Since it was formulated, the Theory of Planned Behavior (TPB) has been extensively used in a great number of studies; whose findings accumulate to the theory's power in predicting intentions and behaviors. According to TPB, an individual's behavior is a function of intention, that is determined by her/his attitude, subjective norms, and perceived behavioral control toward such behavior (Ajzen, 1991). TPB proposes that a behavior is performed when individuals believe there are more positive outcomes out of the behavior than the other way around; when they believe the significant others in their environment expect such behavior; and when they are confident with their ability to perform a particular behavior (Sussman \& Gifford, 2019). In the middle of the Covid-19 pandemic and under clear yet hidden threat of stunting, will TPB defends its predictability power? In response to Handayani (2010) who pointed out the importance of a new cross-application of Psychology and Public Health, how likely Communication study - particularly health promotion - can work jointly with TPB in sharpening intentions and eventually leading to performing riskmitigating behaviors. Moreover, this question may lead researchers in Psychology to generate more evidences, both good and poor parenting practices in Indonesia as recommended by Kiling-Bunga et al. (2020).

This article borrows the Theory of Planned Behavior (TPB) as the basis to make sense of these four healthy behaviors with risks associated to two big threats to human health: HWWS, social distancing, and wearing a mask as the most frequent advices during the corona pandemic and 
its counterpart pillar of open defecation free (ODF) vis-à-vis stunting phenomenon. Specifically, it aims to synergize the risk communication model and TPB in mitigating health risk factors.

\section{Discussion}

\section{Gaining Knowledge of Health Risk}

As a principle of hygienic behavior, handwashing is suggested at critical times that include before and after eating a meal, after defecation, and after caring for the sick among others. Notably, during this pandemic, hand hygiene becomes the most important measure to prevent virus transmission (WHO, 2020). Understandably, when Covid-19 started threatening human life, there was a massive and simultaneous flow of messages to perform handwashing beyond the previously suggested critical times. Suddenly everyone is highly concerned about their own and others' hand hygiene, everyone is doing health promotion, sharing knowledge about hygiene behavior. People perceive a high risk of Covid infection if they neglect hand hygiene.

Among others, perception of health risk is developed based on knowledge (De Santis, Hauglum, Deleon, ProvencioVasquez, \& Rodriguez, 2017; Tarannum, Kansal, \& Sharma, 2018) and personal experience (Lujala, Lein, \& Rød, 2015; Ohman, 2017). Individuals need information to allow them to build an accurate perception of healthy vs risk behavior toward Covid-19, stunting, and other threats. Individuals engage in informationseeking behavior to learn about riskmitigating behavior. However, only when they have a sufficient amount of informa- tion and from reliable sources that they can perceive risk more accurately. Researchers highlighted the contribution of information needs, risk perception, and current knowledge as direct predictors of intention to seek information (Huurne \& Gutteling, 2008). According to Tennant et al. (2015), when individuals have six literacies - which include traditional practices, media, science, and health literacy - their understanding of information seeking and sharing will be improved, leading to better decision making, and eventually taking riskmitigating behaviors.

First, several weeks since Covid-19 strikes, conventional communication channels as well as digital social media platforms were flooded with an abundant flow of information about Covid-19 and how to protect oneself from being infected. Those messages come in various media and formats; electronically and verbally passed around. Understandably, using positive advertising has been recommended for decades ago (Liu, Huang, \& Brown, 1998). In more recent years, the Government of Indonesia has been engaging public figures including actors and musicians in health campaigns toward Covid-19 prevention (Saputra, 2020). Emerging health promotion amateurs across the country exercise their skill and creativity in formulating and conveying risk-avert behavior to combat Covid-19 resulting in various designs of health promotion messages. However, since intentionally deceiving information is also found during Covid pandemic, community members should carefully follow only those coming from trusted sources (Bafadhal \& Santoso, 2020). 
Amazed by the improved hand hygiene in response to the Covid-19 threat, we may wonder if there are additional variables that come into play during the pandemic, such as knowledge and risk perception. Further studies revealed knowledge as a significant contributor to the development of all three determinants (Dumitrescu, Wagle, Dogaru, \& Manolescu, 2011). While knowledge is a key determinant of intention (Dumitrescu et al., 2011; Lou et al., 2014; Siddique, 2012), other researchers found it an equally significant determinant to an individual's behavior (Levine \& Strube, 2012). People gain knowledge of hygiene practices and directly watch public figures demonstrate proper handwashing. Intense flow of audiovisual hand-washing message delivered right into one's gadgets. The majority of people are anxious when they don't wash or clean their hands with hand sanitizer. Individuals take control of others' hygiene practices. They become extremely cautious with hand hygiene that a common gesture of handshake is even suspended in fear of unwashed hands. Understandably, a new social norm is established, HWWS is appropriate and doubtful washed hands are not acceptable.

Despite scientists are struggling to better understand the characteristics of The Coronavirus and at the same time searching for its remedy, there are some lessons we can draw from this pandemic. Promotion of health messages - particularly handwashing with soap - experiences a tremendous highlight where everyone becomes a health promoter. There are several interesting observations about communicating health risks during Covid-19 pandemic.
Massive and intensive risk communication effectively helps people acquire knowledge about the consequences of personal and social behavior toward the spread of Covid-19. Especially in term of hand hygiene, there was a panic buying of hand sanitizer gels and alcohol. Liputan6.com reported Covid-19 triggered panic buying of several products made known to public as to minimize the risk (Putra, 2020). In compensation of scarcity, there has been a blow in of information - accurate or otherwise - on how to make their hand sanitizer. Even Kontan.co.id a reputable media focuses on economic released an article to teach its readers how to make their own hand sanitizer (Biananda, 2020). Probably, the catastrophic circumstances overruled people's rationality and activated their emotional buttons in responding to the crisis. On the other hand, it is also possible that the pandemic shuts down people's perception and prompt them to brute fact about this real threat to human life when they make health decision. To some extent, handwashing seems like live-saving behavior for most people when facing the pandemic. Later disclosed information to prioritize handwashing might account for over-reliance on hand sanitizer as means to maintain hand hygiene. Both people's immediate response and later amendment demonstrate how the application of ehealth - promoting healthy behavior using modern technology - produced expected target behavior effectively and at social scale.

Improved knowledge on hand hygiene builds up awareness or paranoia leading people to change behavior as evident in their newly constructed straightforward hand-wash- 
ing station at homes, workplaces, and public spaces or rubbing their hands unreasonably often. Behavior change initiatives toward washing hand with soap has been promoted by government as well as development agencies far before this pandemic strike. Especially this year, global hand-washing day is observed with deep concern to slow down the virus spread (Putsanra, 2020). After almost ten months since the first case found in this country, Ministry of Health observed this pandemic has successfully triggered behavior change in terms of washing hands with soap (Prasasti, 2020; Unicef, 2020). In contrary to their behavior before Covid-19 pandemic where health promotion on sanitation that covers handwashing at critical times, currently hand hygiene maintenance is excessively performed. While there is a sense of pleasure because such behavior change happened drastically, one may awkwardly ask why it took a pandemic to bring about this hygienic attitude?

The route from risk communication to knowledge acquirement, awareness cultivation, intention forming, and eventually to performing hand hygiene behavior might enrich existing health behavior theories from the perspective of catastrophic circumstances. An interesting discovery may prove whether factual risks alone contributes to this behavior change; or how sustained hand hygiene behavior after Covid-19 is over. A recent descriptive study concludes less only $27 \%$ of people visiting a public market in Medan wash their hand as recommended although they are aware of the risk of Covid-19 (Siahaineinia \& Bakara, 2020). A conflicting finding was presented by Wise,
Zbozinek, Michelini, Hagan, and Mobbs (2020) that it took five days for respondents to change their perceptions of being infected and eventually perform protective behavior such as washing hand and social distancing. These researchers argued that perception toward likelihood of being personally predicted the performance of protective behavior, more than likelihood of transmission of its severity.

In contrast to health promotion to prevent Covid-19, communication of risk factors leading to stunting has been heavily focusing on nutrition-specific determinants, noticeable in far fewer studies designed to understand nutritionsensitive factors (Chamilia \& Triska, 2017; Rosha, Sari, Amaliah, \& Utami, 2016; Torlesse, Cronin, Sebayang, \& Nandy, 2016) compared to those of nutritionspecific (Gizi Politeknik Kesehatan Kemenkes Bandung \& Korespondensi, 2017; Heryanto \& Martha, 2019; Masithah \& Martianto, 2005; Nabuasa, C.D, Juffrie, M, dan Huriyati, 2013; Rahmad, 2016). Compare to Covid-19, communication of risk factors of stunting seems far less massive and comprehensive, particularly on hygiene aspect as it over-emphasizes nutrition in-take resulting under-estimate open defecation behavior as a key risk factor for stunting.

Similar to handwashing is a key preventive behavior to protect people from Covid-19 exposure, stop defecating in the open is significantly minimize risks for stunting. From the perspective of its costly consequences both for individual child as well as a country, stunting is no less harmful than Covid-19. However, unlike the uncontrollable speed of Covid- 
19 transmission, many of stunting risks are actually within control at individual, community as well government levels. Take ODF practice which is heavily associated with lower stunting prevalence as an example. While strongly supported by research findings as a major risk, defecating in the open behavior may not be as complicated to be changed. Moreover, there is no transmission risks at all in terms of stunting. Rather, having owned latrine alone is a major move to prevent stunting (Spears, 2013; Spears, Ghosh, \& Cumming, 2013). A comparison between having a household to defecate safely in a toilet and extending control to other people's hand-washing behavior demonstrates how the former is less complicated to do than the latter because an individual's hand hygiene is out of control of someone else's.

\section{Health Risk Perception and Communication}

A recent literature review in health risk communication involving 4,469 potential articles highlighted variables such as the congruency of message with targeted groups' cultural belief, formulation of understandable messages to audience, involve credible and trustworthy message carriers, and the use of effective communication materials and channels as critical aspects of risk communication strategy (Boyd \& Furgal, 2018). Moreover, engaging local leaders is also proposed by Liem et al. (2019) who recommend shamans in promoting toilet defecation and stop defecating in the open.

Researchers studying risk perceptions discovered higher flu risk perception generates much greater intentions to get vaccinated (Oghogho et al., 2019). A former study about risk perception when part of this world was hit by Middle East Respiratory Syndrome (MERS) in 2015 ago consistently highlights a positive association between risk perception and people's intention to prevent transmission (Kim \& Song, 2017). Referring to Miller and Barnett (2010), risk is perceived highest when people fear they do not have control over the hazard, and when they cannot avoid exposing to the hazard. Meaning, it takes accurate perceptions of health risks to lead people to perform health behavior. However, studying social distancing during the Covid-19 pandemic, Herdiana (2020) discovered low obedience even though individuals are aware of the risk factors and the fatal consequences of nonobservance. This might be due to the fundamental need to socialize with other human beings. Contradictory to stunting, which is broadly perceived as hereditary, leading to low perceived behavior control, health promotion of Covid-19 heavily gains benefits from massive communication of its risk factors. Besides, government-issued regulations and provide substantial funding to ensure community members perform health behavior to avert the disease.

Community, including households with children under five, have not been well-informed of such findings. Studies reveal misperception of children's short posture as hereditary instead of the result of under-nutrition problem (Liem, Panggabean, \& Marta, 2019; Millenium Challenge Corporation, 2019). While researchers discovered a significant relationship of risk perception with performing health behavior (McLaughlin \& Walsh, 2011; Niens, Strack, \& Marggraf, 
2014; Rosen \& Kostjukovsky, 2015), it is understood that such misperception on stunting may be counter-productive to its reduction strategy because mothers and other primary caregivers tend to accept their children's short posture as genetics; and consequently, they lack the intention to address stunting risk factors.

In the context of the pandemic, a study involving more than 13,000 respondents, Walter, Böhmer, Reiter, Krause, and Wichmann (2012) discovered informationseeking behavior is higher when influenza $\mathrm{A}(\mathrm{H} 1 \mathrm{~N} 1)$ first knocked and decreasing in later months. Collected information is then used in weighing how much risk individuals attach to a particular object or behavior. Therefore, lack of information about risk factors to a disease entails familiarity with the risk (Carlton \& Jacobson, 2013). Furthermore, Carlton and Jacobson also revealed that risk characteristics alone - such as the likelihood of occurring and consequences - lacks predictability toward risk perception, because individuals engage in both cognitive and affective processes in analyzing risks. To increase intentions toward the performance of health behavior, not only an effective health promotion strategy is required. Equally important is that health promoters not over-looking its timely implementation, i.e. when risk perception is high.

From Risk Communication to Application of Risk-mitigating Behavior

Despite both hygiene practices are fundamental for human health, why liberating community members from open defecation behavior does not seem to progress at the expected speed? On the other hand, the practice of handwashing becomes so prevalent all over the place just in a matter of months. Stunting reduction advocates deserve answers to a question such as "what will it take to generate equally substantial collective behavior change to arrive at the ODF community?" One may rely on a better understanding of how people perceive risk and its communicating strategy.

Figure 1 shows the hypothetical role of risk communication and TPB in generating the intention to perform risk-mitigating behaviors. According to $\mathrm{TPB}$, intention and perceived-behavioral control are important precursors of behavior; while intention itself is determined by attitudes, subjective norms, and perceived behavioral control (Ajzen, 1991). Figure 1 shows risk-mitigating behavior is driven

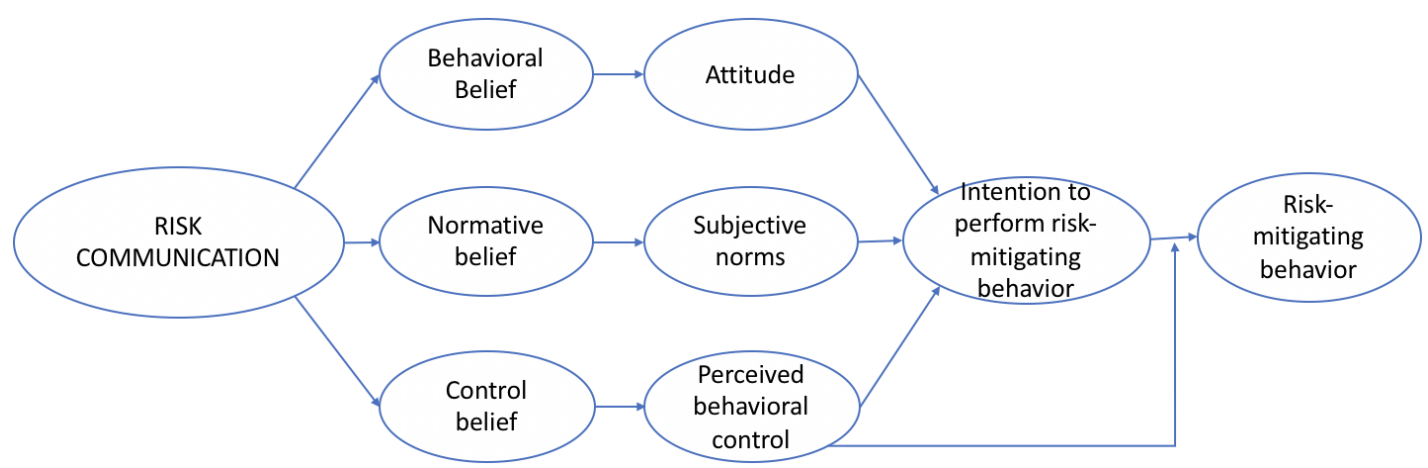

Figure 1. Theory of planned behavior - addressing Covid-19 pandemic and stunting 
by one's intention to do so, self-protection may be an intention that drives a person not to shake hands with others. Ajzen believed people's evaluation of the outcomes of performing a behavior has direct influence to the intention formation, that is their feeling of unsafe after shaking hands with others during this difficult time may lead them to refrain from such gesture. Intention is also determined by individuals' subjective norms that represent their belief whether or not significant others expect them to engage in a particular behavior. A giant reminder on the wall demonstrating wearing mask as an accepted behavior is more likely to lead whoever entering the room to put on their mask because it is quite clear that is the expected behavior. Similarly, Covidinfected individuals' perceived control to refrain from hugging family members may directly influence either the intention or behavior of actually not hugging them. The degree of how much they believe they are in control to prevent infecting other family members may influence their confidence not to show this ordinary act of love. Facing similarly threatening impacts of Covid-19 and stunting, continuously and regularly communicating any risk related to both threats may feed people's underlying beliefs, attitudes, subjective norms, and perceived-behavioral control toward the intention and performance of required mitigating-risk behaviors.

In the ordinary scenario, most of TPB studies discovered attitude, subjective norms, and perceived behavioral control are strong predictors of one's intention toward a behavior. Nevertheless, in pandemic one, an increasing number of infections and deaths might play a role in magnifying the risk to be transmitted. Moreover, a big wave of knowledge flow in different formats about various prevention measures present behavior modeling more readily. There seems an interplay of TPB and risk communication - especially health promotion - deserves more research interests. In regard to Covid-19, some local leaders in Indonesia combined risk communication with community mobilization in minimizing infection risks, including Jogo Tonggo innovation. Under this program, the governor himself together with other public figures consistently demonstrate risk-mitigating behaviors aiming at influencing the right attitudes, subjective norms, and perceived-control toward both intention and risk-mitigating behavior. This strategy of risk communication complements village government's crucial role in conveying the dos and don'ts through community media and village corners, making sure compliance, coordinating with other stakeholders, and taking immediate actions to help villagers who are infected (Arditama \& Lestari, 2020; Pemerintah Provinsi Jawa Tengah, 2020). Another innovation comes from West Java, Pikobar (Pusat Informasi \& Koordinasi Covid-19 Jawa Barat). This application provides a broad range of information about Covid-19, including common and uncommon symptoms and how to self-diagnose, social distancing policy, financial aid, even online learning schedule for school-age children (Pemerintah Provinsi Jawa Barat, 2020).

In contrast to Covid-19, risk communication in stunting seems much less intense. Probably given its wide range of risk factors, health promotion on stunting seems to target too many aspects. 
Although it may be true, focusing on critical information about stunting may help community members - households with pregnant women and children under five - sorting out misbeliefs of short body posture as heredity. Less likely such belief may result in best efforts from mothers and caregivers to engage in stunting riskmitigating behaviors. Ministry of Health has profound health promotion messages about risk factors of stunting (Kementerian Kesehatan Republik Indonesia, 2019), but how effective the risk communication has reached targeted group of people, how local leaders have endorsed the messages to their community members, and how well-informed community members about stunting, as well as their intention to engage in mitigating the risks remain further reflections.

Communication theories offer a strategy to disseminate health promotion messages effectively. Relying on its ecological perspective and multilevel strategies - including individual, group, social marketing, media advocacy, and mass media campaigns - public health communications investigate suitable strategies to reach targeted stakeholders with well-suited messages in a more persuasive tone. (The National Cancer Institute, 2005). As a new communication technology, "e-health" relies on modern information technologies and intersects with medical informatics, public health, and business aimed at helping people stay healthy (Eysenbach et al., 2001). The role of e-health in pandemic management has been outlined in each of the 10 outbreak investigation steps, including the outbreak notification and communication of corresponding health risks (Li \& Ray,
2010). During the recent pandemic, where so many alerts to maintain hand hygiene to control the virus spread come into and go out from everyone's gadgets has offered bold evidence of the significant contribution of e-health utilization.

\section{Conclusion}

Although only recently appeared, Covid19 continuously infecting millions of people worldwide. Experts identified risky behavior and recommend some riskmitigating behavior which require collective undertaking from all community members. However, individuals' intention to engage risk-mitigating behavior is determined by their attitude, subjective norms, and perceived-behavioral control which are built upon adequate information about the threats and how to minimize the risk. Massive risk communication on Covid-19 has triggered deep concern to follow instructions on hand hygiene, wearing masks, and social distancing. In addition, leaders' demonstration of riskmitigating behavior resulted in high compliance rate, probably because little yet has been discovered about this virus so relying on experts may simply a reasonable decision. On the other hand, communication of stunting risk factors does not receive as much support as for Covid-19. Besides, community members have their own perception that one's body figure is given by nature, so they tend to use this misbelief to disregard the actual risk.

Especially for Indonesian rural communities where body-height is broadly perceived as hereditary, this comparative review should inform health workers and 
community leaders alike the importance to magnify health promotion efforts in overpowering the misbelief. Not only in Indonesia, failing to do so, may bring a likely implication emerged as a serious obstruction to the effective implementation of stunting reduction program in other countries with similar misperception.

With this regard, putting together literature on risk perception, $\mathrm{TPB}$, and communication studies may help health authority in designing effective risk communication. E-health which includes using social media is a promising strategy to mobilize community members into health promotion. Health workers may take the snapshot of hand hygiene behavior change during this pandemic to later consider utilizing the e-health concept to convey a complete picture of stunting and demonstrating recommended behavior to reduce risks of stunting. Moreover, local leaders' direct involvement is highly suggested, not only in communicating the risks, but also to set the right attitude and norms, as well as to install collective confidence among community members to control the threats.

\section{References}

Adjibolosoo, S. V. K., Adongo, P. B., Tawiah-Yirenya, D., Ofori, B. D., \& Afranie, S. (2017). Behavioural factors that influence open defaecation among first cycle school pupils in the eastern and volta regions of Ghana. International Journal of Current Research In Biology And Medicine, 2(9), 1-16. doi: $\underline{10.22192 / \mathrm{ijcrbm} .2017 .02 .09 .001}$

Ajzen, I. (1991). The theory of planned behavior. Organizational Behavior and
Human Decision Process, 50, 179-211. doi: $10.4135 / 9781446249215 . n 22$

Arditama, E., \& Lestari, P. (2020). Jogo Tonggo: Membangkitkan kesadaran dan ketaatan warga berbasis kearifan lokal pada masa pandemi Covid-19 di Jawa Tengah. Jurnal Pendidikan Undiksha, 8(2), 157-167.

Bafadhal, O. M., \& Santoso, A. D. (2020). Memetakan pesan hoaks berita COVID-19 di Indonesia lintas kategori, sumber, dan jenis disinformasi. Jurnal Magister Ilmu Komunikasi, 6(2), 235249.

Biananda, B. (2020). Cara membuat hand sanitizer sendiri, aman dan sesuai aturan. Retrieved from

https://kesehatan.kontan.co.id/news/ca ra-membuat-hand-sanitizer-sendiriaman-dan-sesuai-aturan

Boyd, A. D., \& Furgal, C. M. (2018). Communicating environmental health risks with indigenous populations: A systematic literature review of current research and recommendations for future studies. Health Communication, 34(13), 1-11. doi: $\underline{10.1080 / 10410236.2018 .1507658}$

Carlton, S. J., \& Jacobson, S. K. (2013). Climate change and coastal environmental risk perceptions in Florida. Journal of Environmental Management, 130, 32-39. doi: 10.1016/j.jenvman.2013.08.038

Chamilia, D., \& Triska, S. N. (2017). Hubungan riwayat penyakit diare dan praktik higiene dengan kejadian stunting pada balita usia 24-59 bulan di wilayah kerja Puskesmas Simolawang, Surabaya. Amerta Nutr, 243251.

Danaei, G. (2016). Evidence on risk factors of stunting. Retrieved from https://cdn1.sph.harvard.edu/wp- 
content/uploads/sites/1540/2017/02/G

Danaei_Evidence-on-risk-factors-ofstunting_1dec2016.pdf

Danaei, G., Andrews, K. G., Sudfeld, C. R., Fink, G., McCoy, D. C., Peet, E., Sania, A., Smith Fawzi, M. C., Ezzati, M., \& Fawzi, W. W. (2016). Risk factors for childhood stunting in 137 developing countries: A comparative risk assessment analysis at global, regional, and country levels. PLoS Medicine, 13(11), $1-18$.

doi:

\subsection{1/journal.pmed.1002164}

De Santis, J. P., Hauglum, S. D., Deleon, D. A., Provencio-Vasquez, E., \& Rodriguez, A. E. (2017). HIV risk perception, HIV knowledge, and sexual risk behaviors among transgender women in South Florida. Public Health Nursing, 34(3), 210-218.

Devine, J. (2009). Introducing SaniFOAM: A framework to analyze sanitation behaviors to design effective sanitation program (Issue October). Retrieved from papers2://publication/uuid/65C6C5AC -31C8-4DF4-A097-FF282EE8335D

Dumitrescu, A. L., Wagle, M., Dogaru, B. C., \& Manolescu, B. (2011). Modeling the theory of planned behavior for intention to improve oral health behaviors: the impact of attitudes, knowledge, and current behavior. Journal of Oral Science, 53(3), 369-377. doi: 10.2334/josnusd.53.369

Eysenbach, G., Köhler, C., Yihune, G., Lampe, K., Cross, P., \& Brickley, D. (2001). A framework for improving the quality of health information on the world-wide-web and bettering public (E-)health: The medcertain approach. Studies in Health Technology and Informatics, 84, 1450-1454. doi: 10.3233/9781-60750-928-8-1450

García Cruz, L. M., González Azpeitia, G.,
Reyes Súarez, D., Santana Rodríguez, A., Loro Ferrer, J. F., \& Serra-Majem, L. (2017). Factors associated with stunting among children aged 0 to 59 months from the central region of Mozambique. Nutrients, 9(5), 1-16. doi: $\underline{10.3390 / \text { nu9050491 }}$

Gargita, I. W., Miswan, M., \& Rosnawati. (2020). Faktor-faktor yang mempengaruhi kepemilikan jamban setelah pemicuan di desa Pantolobete wilayah kerja Puskesmas Lalundu Despot Kecamatan Rio Pakava Kabupaten Donggala. Jurnal Kolaboratif Sains, 1(1), 316-329.

George, C. M., Oldja, L., Biswas, S., Perin, J., Lee, G. O., Kosek, M., Sack, R. B., Ahmed, S., Haque, R., Parvin, T., Azmi, I. J., Bhuyian, S. I., Talukder, K. A., Mohammad, S., \& Faruque, A. G. (2015). Geophagy is associated with environmental enteropathy and stunting in children in rural Bangladesh. American Journal of Tropical Medicine and Hygiene, 92(6), 1117-1124. doi: 10.4269/ajtmh.14-0672

George, C. M., Oldja, L., Perin, J., Sack, R. B., Biswas, S., Ahmed, S., Shahnaij, M., Haque, R., Parvin, T., Azmi, I. J., Bhuyian, S. I., Talukder, K. A., \& Faruque, A. G. (2016). Unsafe child feces disposal is associated with environmental enteropathy and impaired growth. Journal of Pediatrics. doi: 10.1016/j.jpeds.2016.05.035

Gizi Politeknik Kesehatan Kemenkes Bandung, J., \& korespondensi, A. (2017). Intervensi gizi spesifik dengan pendampingan gizi terhadap status gizi balita di Kabupaten Bandung Provinsi Jawa Barat. Jurnal Riset Kesehatan, 9(1).

Handayani, L. (2010). The role of social support, knowledge, attitude, and 
self-efficacy in breastfeeding: Social cognitive perspective. Buletin Psikologi, 18(1), 13-18.

Herdiana, D. (2020). Social distancing: Indonesian policy response to the corona virus. Jurnal Ilmu Administrasi, 17(1), 93-110.

Heryanto, H., \& Martha, E. (2019). Kajian faktor penyebab dan intervensi gizi spesifik untuk pencegahan stunting di Kabupaten Lampung Utara. Jurnal Kesehatan Masyarakat Aceh (JUKEMA), 5(2), 413-425.

Huurne, E. Ter, \& Gutteling, J. (2008). Information needs and risk perception as predictors of risk information seeking. Journal of Risk Research, 11(7), 847-862.

doi:

$\underline{10.1080 / 13669870701875750}$

Junias, M. S., Mukono, J., \& Purnomo, W. (2016). Factors of knowledge and toilet availability in affecting behavior of open defecation. International Journal of Scientific and Research Publications, 6(5), 300-303.

Kasri, R. Y., Wahyuningrum, Y., \& SNV. (2019). Sustaining ODF and moving towards safely managed sanitation: Lesson learned from three districts/cities. Retrieved from

https://devjobsindo.org/ngojobs/sustaining-open-defecation-freeodf-city-districts-in-indonesiaresearch-re-advertised/

Kementerian Kesehatan. (2016). Infodatin Balita Pendek. Retrieved from https://www.kemkes.go.id/resources/d ownload/pusdatin/infodatin/situasibalita-pendek-2016.pdf

Kementerian Kesehatan Republik Indonesia. (2019). Pencegahan stunting. Retrieved from https://promkes.kemkes.go.id/pencega han-stunting
Kiling-Bunga, B. N., Margiani, K., \& Kiling, I. Y. (2020). Parenting research in Indonesia: What we have done so far. Buletin Psikologi, 28(1), 59. doi: $\underline{10.22146 / \text { buletinpsikologi.51578 }}$

Kim, C. W., \& Song, H. R. (2017). Structural relationships among public's risk characteristics, trust, risk perception and preventive behavioral intention The case of MERS in Korea -. Crisis and Emergency Management, 13(6), 85-95. doi:10.14251/crisisonomy.2017.13.6.85

Kurniawan, I. (2020). Gugus tugas Jabar catat 637.102 pelanggaran protokol kesehatan Covid-19. Retrieved from https://prfmnews.pikiranrakyat.com/jawa-barat/pr13782083/gugus-tugas-jabar-catat637102-pelanggaran-protokolkesehatan-covid-19

Levine, D. S., \& Strube, M. J. (2012). Environmental attitudes, knowledge, intentions and behaviors among college students. Journal of Social Psychology, 152(3), 308-326. doi: $\underline{10.1080 / 00224545.2011 .604363}$

Li, J. H., \& Ray, P. (2010). Applications of E-Health for pandemic management. 12th IEEE International Conference on EHealth Networking, Application and Services, Healthcom 2010. doi: 10.1109/HEALTH.2010.5556536

Liem, S., Marta, R. F., \& Panggabean, H. (2019). Sanitation behavior and risk of stunting: Understanding the discourse of a public service announcement. The Mesenger, 11(2), 168-181. doi: $\underline{10.26623 / \text { themessenger.v11i2.1317 }}$

Liem, S., Panggabean, H., \& Marta, R. F. (2019). Persepsi sosial tentang stunting di Kabupaten Tangerang. Jurnal Ekologi Kesehatan, 18(1), 37-47.

Liu, S. P., Huang, J. C., \& Brown, G. L. (1998). Information and risk percep- 
tion: A dynamic adjustment process. Risk Analysis, 18(6), 689-699.

Lou, Z., Zeng, G., Orme, J. G., Huang, L., Liu, F., Pang, X., \& Kavanagh, K. F. (2014). Breastfeeding knowledge, attitudes, and intention in a sample of undergraduate students in Mainland China. Journal of Human Lactation, 30(3), 331-339. doi: $10.1177 / 0890334414526058$

Lujala, P., Lein, H., \& Rød, J. K. (2015). Climate change, natural hazards, and risk perception: the role of proximity and personal experience. Local Environment, 20(4), 489-509. doi: $\underline{10.1080 / 13549839.2014 .887666}$

Masithah, T., \& Martianto, D. (2005). Hubungan pola asuh makan dan kesehatan dengan status gizi anak balita di Desa Mulya Harja. 29(2), 29-39.

Millenium Challenge Corporation. (2019). Community-based health and nutrition to reduce stunting project. Star report: Indonesia compact. Retrieved from https://www.mcc.gov/resources/story/ section-ind-star-report-health-project

McLaughlin, A. C., \& Walsh, F. (2011). Individual differences in judgments of hand hygiene risk by health care workers. American Journal of Infection Control, 39(6), 456-463. doi: 10.1016/j.ajic.2010.08.016

Miller, B. M., \& Barnett, B. (2010). Understanding of health risks aided by graphics with text. Newspaper Research Journal, 31(1), 52-68. doi: $\underline{10.1177 / 073953291003100105}$

Nabuasa, C.D, Juffrie, M, dan Huriyati, E. (2013). Riwayat pola asuh, pola makan, asupan zat gizi berhubungan dengan terhadap kejadian stunting pada anak usia 24-59 bulan di Kecamatan Biboki Utara Kabupaten Timor Tengah Utara Provinsi Nusa Tenggara
Timur. Jurnal Gizi dan Dietetik Indonesia, 1(3), 31-43.

Niens, C., Strack, M., \& Marggraf, R. (2014). Parental risk perception of mycotoxins and risk reduction behaviour. British Food Journal, 116(6) 1014-1030. doi: 10.1108/BFJ-10-2012$\underline{0260}$

O'Connell, K. (2014). What Influences Open defecation and latrine ownership in rural households? - Findings from a global review. Sustainable Sanitation Alliance. Retrieved from https://www.susana.org/en/knowledg e-hub/resources-andpublications/library/details/2362

Odagiri, M., Muhammad, Z., Cronin, A. A., Gnilo, Mi. E., Mardikanto, A. K., Umam, K., \& Asamou, Y. T. (2017). Enabling factors for sustaining ODF communities in rural Indonesia. International Journal of Environmental Research and Public Health, 14, 1572. doi: doi: 10.3390/ijerph14121572

Oghogho, E., Daniel, E. V., Othmand, A., Wuyke, G., Agarwal, R., Suarez, S., \& Darrow, W. (2019). Seasonal influenza risk perception and intention to vaccinate among university students: A Crosssectional study. APHA's 2019 Annual Meeting and Expo. Retrieved from https://apha.confex.com/apha/2019/me etingapp.cgi/Paper/440908

Ohman, S. (2017). Previous Experiences and risk perception: The role of transference. Journal of Education, Society and Behavioural Science, 23(1), 1-10. doi: 10.9734/jesbs/2017/35101

Pemerintah Provinsi Jawa Barat. (2020). Jadwal siaran dan materi pembelajaran untuk program Belajar Dari Rumah hari Minggu 18 Oktober 2020. Pusat Informasi \& Koordinasi Covid-19 Jawa Barat. Retrieved from 
https://forum.pikobar.jabarprov.go.id/ c/jdwal-belajar-dari-rumah/19

Pemerintah Provinsi Jawa Tengah. (2020). Warga gotong royong "Jogo Tonggo" lawan Covid-19. Retrieved from https://jatengprov.go.id/publik/wargagotong-royong-jogo-tonggo-lawancovid-19/

Perez, E., Coombes, Y., Devine, J., Grossman, A., Kullmann, C., Kumar, C. A., Mukherjee, N., Prakash, M., Robiarto, A., Setiwan, D., Singh, U., Eduardo, B., \& Cardosi, J. (2012). What does it take to scale up rural sanitation? In Sanitation and Hygiene in Africa: Where do we stand (Issue July). Sustainable Sanitation Alliance. Retrieved from

https://www.susana.org/en/knowledg e-hub/resources-and-

publications/library/details/1565

Prabowo, K. W. (2020). 5.815 pelanggar protokol Covid-19 di hari ke-6 operasi yustisi. Retrieved from

https://www.medcom.id/nasional/met ro/Rb10JxXN-5-815-pelanggarprotokol-covid-19-di-hari-ke-6operasi-yustisi

Prasasti, G. D. (2020). Kemenkes: Pandemi COVID-19 jadi pengingat kuat pentingnya cuci Tangan pakai sabun. Retrieved from https://www.liputan6.com/health/read /4382944/kemenkes-pandemi-covid19-jadi-pengingat-kuat-pentingnyacuci-tangan-pakai-sabun

Putra, G. S., \& Selviana, S. (2017). Faktorfaktor yang berhubungan dengan kepemilikan jamban sehat di Desa Empakan Kecamatan Kayan Hulu. Jurnal Kesmas (Kesehatan Masyarakat) Khatulistiwa, 4(3), 238 . doi: 10.29406/jkmk.v4i3.866

Putra, N. P. (2020). HEADLINE: Virus
Corona picu panic buying makanan, masker, hand sanitizer, Bagaimana meredamnya? Retrieved from

https://www.liputan6.com/news/read/ 4193886/headline-virus-corona-picupanic-buying-makanan-masker-handsanitizer-bagaimana-meredamnya

Putsanra, D. V. (2020). Hari cuci tangan sedunia 15 oktober 2020 \& kaitannya dengan pandemi. Retrieved from https://tirto.id/hari-cuci-tangansedunia-15-oktober-2020-kaitannyadengan-pandemi-f5Wr

Rah, J. H., Cronin, A. A., Badgaiyan, B., Aguayo, V., Coates, S., \& Ahmed, S. (2015). Household sanitation and personal hygiene practices are associated with child stunting in rural India: A cross-sectional analysis of surveys. In BMJ Open. doi: 10.1136/bmjopen-2014$\underline{005180}$

Rahmad, A. H. Al. (2016). Malnutrisi pada balita pedesaan dengan perkotaan berdasarkan karakteristik keluarga: Data Psg 2015 malnutrition a toddler rural and urban areas based family characteristics: Mns 2015. Idea Nursing Journal, VII(2), 43-52.

Rosen, L., \& Kostjukovsky, I. (2015). Parental risk perceptions of child exposure to tobacco smoke. BMC Public Health, 15(1). doi: 10.1186/s12889-015-1434-x

Rosha, B. C., Sari, K., SP, I. Y., Amaliah, N., \& Utami, N. H. (2016). Peran Intervensi gizi spesifik dan sensitif dalam perbaikan masalah gizi balita di Kota Bogor. Buletin Penelitian Kesehatan, 44(2), 127-138. doi: 10.22435/bpk.v44i2.5456.127-138

Saputra, A. (2020). Pemerintah minta peran serta artis dan musisi cegah penularan Corona Covid-19. Retrieved from https://www.liputan6.com/showbiz/re 
ad/4215905/pemerintah-minta-peranserta-artis-dan-musisi-cegah-

penularan-corona-covid-19

Septiani, A. (2020). Satgas COVID-19: Ada 243 Pelanggaran protokol kesehatan di masa kampanye pilkada. Retrieved from https://health.detik.com/beritadetikhealth/d-5177253/satgas-covid19-ada-243-pelanggaran-protokolkesehatan-di-masa-kampanye-pilkada

Siahaineinia, H. E., \& Bakara, T. L. (2020). Persepsi masyarakat tentang penggunaan masker dan cuci tangan selama pandemi Covid-19 Di Pasar Sukaramai Medan. Wahana Inovasi, 9(1), 172-176.

Siddique, M. A. M. (2012). Explaining the role of perceived risk, knowledge, price, and cost in dry fish consumption within the theory of planned behavior. Journal of Global Marketing, 25(4), 181-201. doi: $\underline{10.1080 / 08911762.2012 .743203}$

Spears, D. (2013). How much international variation in child height can sanitation explain? Policy Research Working Papers. Retrieved from https://elibrary.worldbank.org/doi/abs /10.1596/1813-9450-6351

Spears, D., Ghosh, A., \& Cumming, O. (2013). Open defecation and childhood stunting in India: An ecological analysis of new data from 112 districts. PLOS ONE. doi: 10.1371/journal.pone.0073784

Tarannum, F., Kansal, A., \& Sharma, P. (2018). Understanding public perception, knowledge and behaviour for water quality management of the river yamuna in India. Water Policy, 20(2), 266-281. doi:10.2166/wp.2018.134

Tennant, B., Stellefson, M., Dodd, V., Chaney, B., Chaney, D., Paige, S., \& Alber, J. (2015). eHealth literacy and Web 2.0 health information seeking behaviors among baby boomers and older adults. Journal of Medical Internet Research, 17(3), 1-16. doi: 10.2196/jmir.3992

Torlesse, H., Cronin, A. A., Sebayang, S. K., \& Nandy, R. (2016). Determinants of stunting in Indonesian children: Evidence from a cross-sectional survey indicate a prominent role for the water, sanitation and hygiene sector in stunting reduction. BMC Public Health, 16(1), 1-11. doi: 10.1186/s12889-0163339-8

The National Cancer Institute. (2005). Theory at a glance: A Guide for health promotion practice. Retrieved from https://cancercontrol.cancer.gov/sites/ default/files/2020-06/theory.pdf

Unicef. (2020). To beat COVID-19, Hand hygiene must become an everyday reality for all Indonesians. Retrieved from https://www.unicef.org/indonesia/pres s-releases/beat-covid-19-handhygiene-must-become-everydayreality-all-indonesians

Walter, D., Böhmer, M. M., Reiter, S., Krause, G., \& Wichmann, O. (2012). Risk perception and informationseeking behaviour during the 2009/10 influenza a(H1N1)pdm09 pandemic in Germany. Eurosurveillance, 17(13), 1-8.

WHO. (2020). Water, sanitation, hygiene and waste management for The COVID-19 virus. Retrieved from

https://www.who.int/publications/i/ite $\mathrm{m} /$ water-sanitation-hygiene-andwaste-management-for-the-covid-19virus-interim-guidance

World Health Organization., United Nations Children's Fund., \& United States Agency for International Development. (2015). Improving nutrition outcomes with better water, sanitation and hygiene: Practical solutions for policy and 
programmes. Retrieved from

https://www.who.int/water_sanitation _health/publications/washandnutritio n/en/

Wise, T., Zbozinek, T. D., Michelini, G., Hagan, C. C., \& Mobbs, D. (2020). Changes in risk perception and selfreported protective behaviour during the first week of the COVID-19 pandemic in the United States. Royal Society Open Science, 7(9). doi: $\underline{10.1098 / \text { rsos.200742 }}$

World Health Organization. (2020). Practical actions in cities to strengthen preparedness for the COVID-19 pandemic and beyond: An interim checklist for local authorities. In World Health Organization (Issue July). Retrieved from https://www.who.int/publications/i/ite m/WHO-2019-nCoV-

ActionsforPreparedness-Checklist-
2020.1

Yulyani, V., Dina Dwi, N., \& Kurnia, D. (2019). Latrine use and associated factors among rural community in Indonesia. Malaysian Journal of Public Health Medicine, 19(1), 143-151.

Zahrotunnimah, Z. (2020). Langkah taktis pemerintah daerah dalam pencegahan penyebaran virus Corona Covid-19 di Indonesia. SALAM: Jurnal Sosial Dan Budaya Syar-I, 7(3). doi: $\underline{10.15408 / \text { sjsbs.v7i3.15103 }}$

Zahtamal, Z., Chandra, F., Restila, R., \& Restuastuti, T. (2020). Defecation behavior in elementary school age children who live along the Kampar River Riau Province. Jurnal Kesehatan Lingkungan, 12(2), 87. doi: $\underline{10.20473 / j k 1 . v 12 i 2.2020 .87-96}$ 